\title{
POLITICIZATION OF IDENTITY IN LOCAL ELECTION AS A SOFT SECURITY THREAT: A Case of 2017 Jakarta Gubernatorial Election ${ }^{3}$
}

\author{
Putri Ariza Kristimanta and Mouliza K.D Sweinstani \\ Center for Political Studies \\ Indonesian Institute of Sciences, Jakarta, Indonesia \\ Corresponding Author Email: putroI8@lipi.go.id
}

\begin{abstract}
The background of this study is the DKI Jakarta 2017 local election, which was followed by a series of demonstration and identity politicization against the prospective candidate from minority groups. A similar pattern had been applied in 2018 local election and 20I9 national election where SARA (shortened from Suku, Agama, Ras, dan Antar-golongan or ethnicity, religion, race, and intergroup relations) is used to mobilize voters through black and negative campaigns. This study aims to explore how the politicization of identity in the DKI Jakarta Gubernatorial Election 2017 can be a soft security threat to human and societal security. By conducting literature studies to related documents, the authors conclude that what happened in DKI Jakarta is categorized as politicized collective identity. The results of the study describe that politicization of identity could cause three effects that can threaten security, namely (I) increasing negative sentiment towards minority groups; (2) increasing the number of cases of persecution and discrimination in the name of religion or ethnicity; and (3) causing community polarization on social media. The study recommends to the government to strengthen national identity, which involves all components of the state and society so that the issue of identity will not be shifted for negative connotation of short-term electoral agenda.
\end{abstract}

Keywords: Jakarta Gubernatorial Election 2017, identity politization, societal security, soft security threats

\begin{abstract}
Abstrak
Latar belakang penelitian ini adalah pemilihan kepala daerah DKI Jakarta 20I7, yang diikuti oleh serangkaian demonstrasi dan politisasi identitas terhadap calon kandidat dari kelompok minoritas. Pola serupa telah diterapkan pada pemilihan lokal 2018 dan pemilu nasional 2019 di mana SARA (singkatan dari Suku, Agama, Ras, dan Antargolongan) digunakan untuk memobilisasi pemilih melalui kampanye hitam dan negatif. Penelitian ini bertujuan untuk mengeksplorasi bagaimana politisasi identitas dalam Pemilihan Gubernur DKI Jakarta $20 I 7$ dapat menjadi ancaman keamanan lunak bagi keamanan manusia dan masyarakat. Dengan melakukan studi literatur pada dokumen terkait, penulis menyimpulkan bahwa apa yang terjadi di DKI Jakarta dikategorikan sebagai identitas kolektif yang dipolitisasi. Hasil penelitian menggambarkan bahwa politisasi identitas dapat menyebabkan tiga efek yang dapat mengancam keamanan, yaitu (I) meningkatkan sentimen negatif terhadap kelompok minoritas; (2) meningkatkan jumlah kasus penganiayaan dan diskriminasi atas nama agama atau etnis; dan (3) menyebabkan polarisasi komunitas di media social. Studi ini merekomendasikan kepada pemerintah untuk memperkuat identitas nasional, yang melibatkan semua komponen negara dan masyarakat sehingga masalah identitas tidak akan bergeser karena konotasi negatif dari agenda pemilihan jangka pendek.
\end{abstract}

Kata kunci: Pilkada DKI Jakarta 20I7, politisasi identitas, keamanan masyarakat, ancaman keamanan lunak 


\section{INTRODUCTION}

In the era of direct election in Indonesia, candidates tend to use all of their resources to win the election by utilized them to be enforced in their political strategies or to counter their competitors. Mieztner (20I4) said that electoral circumstance in Indonesia after the 20I4 Presidential election is colored by the used of identities-especially religion, ethnicity, and ideology to counter the competitors. This identity politicization is continuously used in other election, for example in the local executive election.

Since 2005 , when Indonesia start to implement the direct election in the local level (Pemilihan Kepala Daerah or Pilkada), conflict and social fragmentation due to the reproduction of identity issues seem to be more often happened (Herdiansyah, 20I7). Whereas, this direct election scheme should aim to bring democracy closer to society and strengthen democracy at the local level, instead of dividing the community. One example of the phenomenon of divided voters due to the use of identity in elections can be seen from the Gubernatorial Election of Jakarta in 20I7. In Pilkada Jakarta, a group of people took the issue of religion and ethnicity as campaign material in order to win one party and on the other hand, to drop the others. The issue of identity even continues to be politicized with the emergence of instigation to not vote the candidates with different religions from voters (Sweinstani \& Hasanah, 20I7).

The social turmoil caused by the use of identity issues used as a tool against the other groups and as a differentiator for each group is reflected in the continuous wave of Aksi Bela Islam (Action for Defending Islam) rally. The rally has been gained sympathy from people outside Jakarta participating in the rally (and other places as well) with the basis of the solidarity of identity similarity. Later, this identity politicization does not end when the winner of the election was announced. Segregation, polarization, and fragmentation of society remain due to differences in political choice. The authors argue that if identity politics with ethnic and religious sentiments are considered successfully mobilized not only the vote but also the sympathizer, political actors will take advantage from this "decay strategy" for bigger political agenda more massively and effectively.

As a response from the government to the chaos of DKI Jakarta Gubernatorial election in 2017, Election Supervisory Board (Bawaslu) makes "identity politics" as their new indicator in the making of 2018 Election Vulnerability Index (Indeks Kerawanan Pemilu - IKP). The inclusion of identity politics as one of IKP's indicator is reasonable because it is in line with Herdiansyah, Junaidi, and Ismiati study in 2017. They argued that the rampant of religion issue discourses and politics after Presidential election in 2014 as well as the massive rallies along Pilkada DKI indicates the strengthening of identity politicization ahead 2019 General Election (Ganjar Herdiansah \& Heni Ismiati, 20I7).

Based on the 2018 Election Vulnerability Index (IKP) issued by Bawaslu, there are eight provinces categorized as the high levels of vulnerability in the identity politics aspect. The eight provinces mentioned are North Sumatra, South Sumatra, West Nusa Tenggara, West Kalimantan, East Kalimantan, Maluku, North Maluku, and Papua. This finding indicates that nearly $50 \%$ of the total of 17 provinces that participated in the 2018 Local Elections are prone to identity politicization (Bawaslu, 20I7). Besides, based on the 20I9 IKP, it portraits the potential vulnerability of 2019 General Election: 5I4 Regencies/City is vulnerable in identity politicization and hate speech through three sub-dimensions, local power relation, campaign, and voter participation (Bawaslu, 20I8).

Several previous studies related to the issue of identity in the election stated that the use of identity issues in elections in Indonesia was caused by a shift from the party-centric to the candidate-centric. This shift actually shows the weakness of party institutionalization which is marked by the personalization of political parties by a handful of people who are able to master resources, which are often linked to mass-based networks that later collaborate to produce and reproduce identity 
issues for electoral interests (Buehler, 2009; C. Fox, 20I8; Ufen, 2008). In regard with the consequences of politicizing identity issue in the electoral mechanism, previous studies stated that this could disrupt political stability and national integration. Taking account that the phenomenon shows that value integration and integrative behavior have not yet been formed in Indonesian society. It is only limited to territorial integration (Herdiansyah, 2017; Sweinstani \& Hasanah, 20I7). Furthermore, the politicization of identity in electoral interests can also lead to a shift in identity politics in the context of populism. Substantive changes in power relations are needed in order to prevent the strengthening of populism and to change elite political domination in the mechanism of liberal democracy (Paskarina, 20I7).

Even though some of these studies have explained the negative impact of identity politicization in 2017 elections from several regions as a potential threat to national disintegration. Among those studies, they rarely explain this phenomenon in the political angle of the national security conception, or more specific, human and societal security.

Therefore, this study was present to fill the gap between the previous studies. This study aims to determine the dynamics of identity politicization as an internal soft security threat to human and societal security by taking a case study of Jakarta's Gubernatorial Election (Pilkada DKI) in 2017.

Besides providing a different perspective from several previous studies, this study is also important because the issue of identity has experienced a shift in use in political interests. Today the escalation of the use of identity issues in politics is more often used for electoral interests with negative connotations. Identity is actually manipulated and merely becomes political rhetoric for elite interests by emphasizing mere primordial sentiment to lead to community fragmentation ultimately. Currently, many parties, including political elites, tend to make identity issues for opportunistic strategies to mobilize identities to improve their status or personal interests (Weinstock, 2006).
Donald L Horowitz in Diamond explained that the negative side of identity politics is that it can provide a clear line to determine who gets included and who gets rejected. In other words, identity politics can be understood as a powerful mechanism to exclude other groups (Horowitz in Diamond, I998). A contemporary view of identity politics also today sees identity politics as a trend or lifestyle, without ideology and partiality, but instead is seen as a celebration. The problem of such identity politics is, even more, shaping its current trend due to the development of modernity and identity construction in social media (virtual platform) (Afala, 20I8). Whereas if we look at the use of identity in politics in the early days of independence, identity is more likely to be used to search for Indonesian identity. For marginal groups, identity is used as a way of gaining recognition from others.

In addition, the authors also base the argument on the importance of this study to be carried out because of the potential sustainable impact of three consecutive elections, namely 2017, 2018, and 2019 Election. It is concerned that the negative effect of Pilkada DKI 2017 will continue until 2019 election, create a polarized and fragmented society, dismiss the national identity, and threaten the socio-political stability of the country. This situation, as stated in Indonesia's Defense White Paper, that social, cultural, primordial, ethnic, racial, and religious dynamics are the drivers of internal conflicts. The pattern of devide et impera or divide the components of the nation in the country is an effective way of disintegrating a country like the Arab Spring phenomenon. If viewed from the perspective of national security, the division of society due to political choice becomes an internal soft security threat to the stability of the state.

Even though this study will analyze how identity can threaten the stability of Indonesia as a nation-state, this study will only focus on what was happening in Jakarta Gubernatorial Election 20I7. Therefore, there are two limitations of this study. (I) This study does not address the identity politics conducted in areas other than Jakarta because the polarization of voters 
from Jakarta is the best example and the most visible in social media and in everyday life. (2) this study does not discuss traditional approach to national security, which is state-centered security in military dimensions, because the development of threats definitions now covers all aspects of human security, multidimensional, and tends to be asymmetric.

\section{METHODS}

The research used a qualitative method, especially descriptive analytics. By using this type of research, the authors will try to explain the 2016-20I7 series of a mass rally in Jakarta chronological event of mass action series in Jakarta as well as analyze the model of constituent elements of that action and finally relate it to the national security, or human and societal security in particular. The data in this study will be obtained from the literature study to related documents and Drone Emprit's social network analysis report.

\section{THEORETICAL FRAMEWORK}

\section{A. Politicized Collective Identity}

The first analytical tool that the author uses in this study is the concept of identity politics, which is seen from the development of identity politics in the politicization of collective identity in political interests. According to Yuval-Davis who places individuals as passive subjects of identity formation, identity is defined as cultural narratives of individuals and certain groups that create equality and, at the same time, construct differences between themselves and other parties, which stably interpret their social position (Yuval-Davis, I997, pp 43). On the contrary, Epstein states that individuals are active and incorporate with others so that they form their respective identities. Such individual behavior supports the opinion of Iris Young which states that social groups in society are not only bound by attributes that are inherent in themselves but also bound by what is called a sense of identity (Dumm \& Young, I992). By this sense of identity, even though a person does not have the characteristics of objective conditions (race, gender, ethnicity, class, region, etc.) which are the same as the majority of people in the group, he/she can still be recognized and acknowledge himself/herself as part of the group due to the strength of a sense of common identity that can transcend the attribute attributes of an identity.

In a political perspective, identity can be interpreted as the use of identity that creates equality and differences between one party and another for certain political purposes. Movements in the name of identity as a binding element of the movement are also often used to protest against existing political conditions. When people become involved in a political protest on behalf of a group, the group's collective identity is being politicized. A politicized collective identity is a form of collective identity that underlies group members' willingness to "engage, as a mindful and self-conscious collective (or as representatives thereof), in a wider power struggle and more inclusive societal context in which this struggle takes place and needs to be orchestrated accordingly." In other words, politicized collective identity can be understood as a form of collective identity that underlies group members' explicit motivations to engage in such a power struggle (Simon \& Klandermans, 200I).

Politicized collective identity is not an all-or-nothing or on-off phenomenon. Instead, the politicization of collective identity and the underlying power struggle unfold as a sequence of politicizing events that gradually transform the group's relationship to its social environment ${ }^{4}$. Typically, this process begins with the first step, that is the awareness of shared grievances 5 . Many scholars such as Klandermans (1997), Lalonde \& Cameron (1994), H. Smith, Spears, \& Oyen (I994), Tajfel \& Turner (I979\&I986), Walker \& Pettigrew (I984), and Wright, Taylor, \& Moghaddam (I990) stated that

$4 \quad$ According to Simon dan Klandermans study in 20oI there are 3 antecedent stages leading to politicized collective identity, those are awareness of shared grievances, adversarial attributions, and involvement of society at large.

5 According to Stekelenburg and Klandermans (I997) awareness of shared grievances can take on different forms. They identified illegitimate inequality, suddenly imposed grievances, and violated principles as important grievances, to which threatened privileges could be added as a fourth type. 
feeling aggrieved as a group is a necessary first step for people to engage in a power struggle on behalf of their group and thus a necessary step toward politicized collective identity (Simon \& Klandermans, 20oI).

Afterward, a political actor is blamed for the group's predicament (adversarial attributions) and claims for compensation are leveled against that actor. Group members then hold an external opponent responsible and become angry at "them" for what they are doing to "us" (Simon \& Klandermans, 20or; Tajfel \& Turner, I979)H. and Turner, J. C. (I979. Unless appropriate compensation is granted, the power struggle continues (involving society by triangulation). If in the course of this struggle, the group seeks to win the support of third parties such as more powerful authorities or the general public collective, identity will be fully politicized. The attempt to involve these parties in the power struggle inevitably turns the issue into a matter of public interest. This final step also results in a transformation of the group's relationship to its social environment because involving a third party implies recognition of society or the larger community as a more inclusive ingroup. Politicized collective identity thus implies a cognitive restructuring of the social environment into opponents and (potential) allies; this also involves strategy reformulation of the conflict issue such that it appeals to potential allies as well (Klandermans, 20I4).

This concept will be used to analyze how the politicized identity in Jakarta Gubernatorial Election in 2017 was formed. By using this concept, we also would like to highlight the interest and scenario behind the massive and continuous action in Jakarta ahead its gubernatorial election. This analysis is useful for making further analysis about how this phenomenon will be called as Indonesia's soft security threat, which is closed to people's social dynamics. For analyzing it as a kind of soft security threat, we provide other analytical tools in the section below.

\section{B. National Security, Societal Security, and Soft Security Threats}

The discourse of soft security threats is closely related to the understanding of the concept of national security and threat perception. The conception of national security is still diverse and trigger debatable discussion among state administrators, academics, and society. The development of the national security concept adapts the dynamics of the global situation after the Cold War. Shifting the perception of threats that were originally oriented to military and state threats (state-centered security), became a multi-dimensional threat that included political, economic, socio-cultural aspects, or people-centered security. This is also influenced by democratization and human rights enforcement that prioritizes the importance of human security against various physical and non-physical threats. Therefore, the security sector is no longer only oriented to state security with traditional threats but has developed into a multi-sector realm that aims to protect people from non-traditional factors.

In reality, in Indonesia, security and threat issues also include security issues that are traditional and non-traditional. However, the real issue of the day the Indonesian government is facing threats that are more traditional than the non-traditional threats. In Indonesia's Defence, White Paper mentioned that the threat to security threats include military and non-military. Essentially, non-military threats using non-military factors assessed as having capabilities that endanger state sovereignty, territorial integrity, and safety of the entire nation. Non-military threats can have ideological, political, economic, socio-cultural, technological, and information dimensions, as well as general salvation (Kementerian Pertahanan, 2015). This concept is also emphasized in the White Paper on German Security Policy and the Future of Bundeswehr, which states that there are fundamental changes in the nature of threats with an extended security concept that includes many new non-military soft security threats such as economic vulnerabilities, environmental challenges, political and societal instabilities (Germany Federal Government, 20I6).

This paper focuses on security concepts and non-traditional threats, or often referred to as soft security threats. In non-traditional approaches, the concept of security is emphasized 
in the security interests of non-state actors. The issue was developed after the decline in military threats but was accompanied by an increase in threats to human security in other aspects such as infectious diseases, natural disasters, environmental damage, and others. As a concept, human security considers that security also covers human security which includes social welfare issues; protection of the rights of community groups; minority groups; children; women from physical violence; and social, economic, and political problems. The discussion of the importance of human security is increasing after the 1994 UNDP Report on Human Rights which explored on 7 dimensions that should be considered in creating human security, namely: economic security, food security, health security, environmental security, individual security, community security, and political security (United Nations Development Programme, 1994, pp. 24-33).

According to Barry Buzan, there are five main According to Barry Buzan, there are five main sectors which are included in the sense of security, namely: (I) military security; which includes two levels of management of state weapons capability both offensively and defensively and the country's perception of intensity with each other; (2) political security; which gives emphasis on the stability of the country's organizations, and ideologies that gave legitimacy to the government; (3) economic security; which encompasses access to power, finance, and markets to support the level of state welfare and strength; (4) societal security; surrounding the continuity of the pattern tradition of language, culture, religion, national identity, and customs including the evolution of acceptable conditions; and (5) environmental security; which pay attention to preserving the environment both locally and globally as an important support system in which human life depends. It should be emphasized that each sector does not stand alone but has strong ties with each other (Fox \& Buzan, I985).

TThe security that will be the focus of this research is societal security, which is one aspect of security described by Buzan. Buzan said that the threat to societal security is influenced by situations inside and outside the country. Buzan also emphasized that societal security is about sustainability, within acceptable conditions for evolution, of traditional patterns of culture, religion, and ethnic identity and custom, then threats to these values much more frequently within the state than outside (Fox \& Buzan, I985). This definition was later confirmed, societal security should be considered as sustainability within acceptable conditions for evolution, of traditional patterns of language, culture and religious and national identity and customs (Wæver, Buzan, Kelstrup, \& Lemaitre, I993). From these definitions, it can be concluded that the threat to the "we" identity will threaten societal security. There are four categories of threats to societal security, namely (I) migration; (2) horizontal competition; (3) vertical competition; (4) depopulation (Buzan, Wæver, \& Wilde, I998). These threats can be minimized by increasing sustainability, resilience, and security (building individual and group security based on central human capabilities) (Ozolina, 20I6). The threat that will be the focus of this research is horizontal competition caused by the politicization of identity with the scope of the Pilkada DKI 2017.

Some key features of soft security threats: (I) responding to internal threats and borders that are not characterized as an element of inter-state relations; (2) the main method in realizing soft security is not using military force, but using efficient internal management of the community with the dimensions of conflict prevention; (3) the capacity to respond to major security threats uses a policy basis; (4) making the concept of security extensive. Soft security threats are more related to social policies and social control issues and require long-term planning, complex policy design, and sustainable work in policy implementation. The results are often not immediately visible (Fatic, 2002). Non-traditional security issues are being portrayed and treated by politicians and practitioners as posing threats to the national sovereignty and territorial integrity of nation-states as well as to the well-being of their respective societies and individuals (Caballero-Anthony \& Emmers, 20I6). 
Then what is the relationship between societal security and the traditional concept of national security? Several states are internally divided into several societal units: conceived nations, ethnic communities, or cultural or linguistic sub-groups. In these cases, societal security and state security may well be negatively correlated, as one may seek to enhance its own security at the other's expense (Theiler, 2003).

From the explanation of the security concept above, we can take an important value in understanding the meaning of security and soft security threats. Security is not only limited to maintaining the territorial boundaries of the country (national sovereignty), but also must guarantee, fulfill, and protect the security of citizens and societal security. The conception of the security and complexity of developing soft security threats, as described above, also reflects that the security system cannot be partially built. The security system must have a comprehensive security approach which involves various parties with different functions and tasks (A'raf, 20I5).

\section{FINDINGS AND DISCUSSION}

\section{A. The Specialty of Jakarta as The Capital City of Indonesia}

As the capital city of Indonesia, the dynamics that occur in the Special Capital Region of Jakarta become the public spotlight and often become a reference for other regions in Indonesia. There are several characteristics of Jakarta which make this area different from other regions. Demographically, DKI Jakarta, which is not only the center of the Indonesian government but also the center of the country's economy, is an area with high population heterogeneity. This condition can even be described as a miniature of heterogeneity in Indonesia because almost all ethnic and religious diversity exists in the city.

Based on the data cited from Provinsi DKI Jakarta Dalam Angka 2018 released by BPS DKI Jakarta, Jakarta total population is I0.374.235. Of these, the 2010 population census noted that $85.36 \%$ of Jakarta's population are Muslim, 7.54\% Christian, 3.I6\% Catholic, 0.21\% Hindu, $3.30 \%$ Buddhist, $0.06 \%$ Kong $\mathrm{Hu} \mathrm{Chu}$, and
0.38\% answered other religions and did not answer (BPS, 20I0). Meanwhile, relating to the composition of ethnic groups inhabiting here, BPS data shows that out of 3I ethnic groups (including ethnic immigrants from Chinese and other foreign ethnic groups) mapped by BPS, all ethnic groups can be found in Jakarta. Of the many ethnic groups that lived in Jakarta, the Javanese, Betawi, Sundanese, Chinese, Batak, and Minangkabau are the most populous ethnic groups in Jakarta.

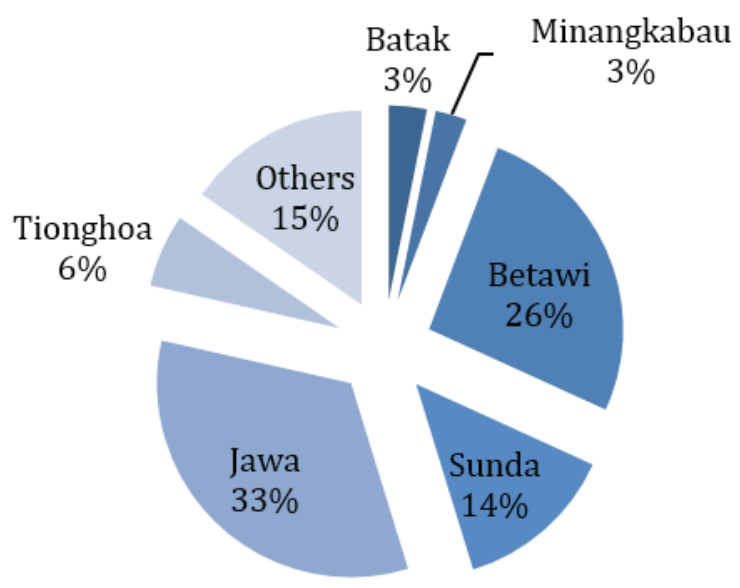

Figure I. Composition of the population of DKI Jakarta based on ethnicity

Source: BPS Population Census 2010, data reprocessed by the author

Meanwhile, in government administration, the status of the specificity of Jakarta as the State Capital City also has a significant impact on distinguishing this region from other regions/ provinces. Based on Law No. 34 of 1999 jo Law No. 29 of 2007 which regulates the specificity of Jakarta as the Capital City of the State, it is known that DKI Jakarta has specific duties, rights, obligations, and specific responsibilities in the administration of government and as the seat of representation of foreign countries, as well as central/representative international institutions. ${ }^{6}$

The distinctive feature of DKI Jakarta as the Capital City that distinguishes the province from other provinces can also be seen from

$6 \quad$ Article 5 Law No. 29 of 2007 
the mechanism of regional head elections. There is only one type of regional head election (Pilkada) in Jakarta, namely the election of the Governor. Unlike the election mechanism in general, which uses a majoritarian formula of $30 \%+$ I, the DKI Jakarta Regional Election uses a majoritarian election system mechanism that has the same principles as the presidential election mechanism. The system used in the DKI Jakarta Regional Election in Two Round System which requires the candidate pair to be able to get a $50 \%+$ I vote in the first round and if it is not fulfilled, then the second round will be held. The requirements for the percentage of votes that are greater than the other regional elections are meant that as a regional leader who has the status of the National Capital, the Governor and Vice Governor of DKI Jakarta need to obtain strong legitimacy. Moreover, with the population very heterogeneous, the leaders of Jakarta need great support from voters who are able to represent the diversity of this region.

In relation to the position of the Governor of DKI Jakarta, implicitly Law No. 29 of 2007 also stated that the position of the Jakarta Governor was higher than the Regional Head / Governor in other regions in Indonesia. It can be seen from several authorities of the Governor of DKI Jakarta, such as Governor of DKI Jakarta has the right to appoint and dismiss the mayor in Jakarta. In Jakarta, the municipal elections do not exist because as the head of the city administration, the mayor appointed by the Governor by the consideration of Dewan Perwakilan Rakyat Daerah (DPRD or Regional People's Representative Council) Jakarta from the civil servants who meet the requirements. It is certainly different from the mayor/regent in other regions selected through the Pilkada mechanism. This authority then clearly differentiates the position of the Governor of DKI Jakarta compared to the position of other governors. It is because only the Governor of Jakarta has this authority.

Governor of DKI Jakarta also has other several duties and authorities that are not owned by other regional heads/governors. The Governor of DKI Jakarta can attend a cabinet meeting concerning the interests of the Capital City. As the capital of the country, the problems and interests of DKI Jakarta also become the national interests 7 . Therefore, in certain cabinet meetings discussing the issue of the capital, the governor of DKI Jakarta was also required to attend the meeting. Another thing that can also differentiate the status and authority of the Governor of DKI Jakarta with other regional heads is that the Governor of DKI Jakarta has protocol rights, including accompanying the President in a state event in accordance with the provisions of the statutory regulations. ${ }^{8}$ For example, in the inauguration of high officials by the President, the Governor of DKI Jakarta is usually invited to attend and accompany the president in the inauguration with cabinet ministers. Due to some specificities of this authority, it can be said that the law implies that the Governor of DKI Jakarta can be equalized with the Minister, even though there is still a need for legal provisions that explicitly regulate this matter.

Looking at some of Jakarta's special aspects, it is natural that the position of the Governor of DKI Jakarta is considered strategic so that it is interesting and challenging for a number of elites and politicians. The candidate pairs of the Governor and Vice Governor of DKI Jakarta are no longer limited to the "regional sons/daughters" but extend to anyone who feels able to lead DKI Jakarta which is considered as an Indonesian miniature. Many public officials, politicians, and even regional leaders feel challenged to lead DKI Jakarta. Experience so far has documented several names like Joko Widodo, Basuki Tjahja Purnama (Ahok), Djarot Saiful Hidayat, Anis Baswedan, and so on. Moreover, the current elite tendency also makes DKI Jakarta as their springboard for a larger political agenda; usually, the big goal is to lead Indonesia in the future. For example, Joko Widodo, who currently serves as President of the Republic of Indonesia 20I4-2019, and Sandiaga Uno, former vice governor of DKI Jakarta, who is currently also running for the vice-presidential candidate in the upcoming 2019 Election. The elite high enthusiasm phenomenon to sit as the Governor

$7 \quad$ Article 26 verse 8 Law No. 29 of 2007

8 Article 3I Law No. 29 of 2007 
of DKI Jakarta implements DKI Jakarta Regional Election as lively as the holding of elections at the national level. It makes the dimension of contestation in the elections in DKI Jakarta have quite high dynamics.

\section{B. The Construction Politicized Collective Identity in Jakarta Gubernatorial Election 2017}

During the DKI Jakarta Regional Election in 20I7, the public was shocked by a series of episodes of mass action that seemed to result in fragmentation of the DKI Jakarta community in particular and Indonesia, in general, became the Religion-Islamic group and the NationalistPluralist group. The tension between the two sides with widespread religious sentiments into ethnic sentiment stems from accusations against Ahok, the Governor of DKI Jakarta at the time, who was considered to have committed blasphemy against Islam when carrying out official speeches in the Thousand Islands Regency (Kepulauan Seribu) in September 2016. Spread pieces of Ahok's speech video which was then used as evidence of the accusation against him and then invited reactions from Islamic groups by conducting a series of demonstrations on behalf of Aksi Bela Islam (Action for Defending Islam).

This action began with a demonstration led by Rizieq Shihab9 (known as Habib ${ }^{\text {1o }}$ Rizieq) in October 2016 which was attended by thousands of people, most of whom came from the Front Pembela Islam (FPI or Islamic Defenders Front). ${ }^{\mathrm{II}}$ Moreover, conservative groups (Burhani, 20I7). This rally was then followed by some other rallies, the last of which was held on 5 May 20I7. The most notable were the ones on 4 November 2016 (known as 4II Action) and 2 December 2016 (known as 2I2 Action), attended by about one million people

\footnotetext{
9 Muhammad Rizieq Shihab is an Indonesian Islamist scholar, the founder, and leader of the Islamist group Front Pembela Islam (Islamic Defenders Front). IO Habib is an Arabic masculine name, with literal meaning "beloved". The name is popular in the Muslim World particularly in the Middle East and Africa. In Indonesia, it is an honour name to address a Muslim scholar of a Sayyid (a descendant of Muhammad) families.

II Front Pembela Islam (FPI or Islamic Defenders Front) is an Islamist political organization formed on I7 August 1998, founded by Muhammad Rizieq Shihab.
}

each. This action then invited various responses from Ahok supporters and from Non-MuslimChinese groups to defend Ahok through the Thousand Candle Action which was carried out after a court ruling stating that Ahok was guilty

What happened in DKI Jakarta at the end of 2016 until mid-20I7 shows that identity is not only formed from what is inherent in an individual, but identity can also be formed from a sense of common social conditions, values, to the ideology that makes a person want to engage himself/herself in certain communal identity that has been formed. In the case of rallies of mass actions in DKI Jakarta, for the Aksi Bela Islam side, their binding values are "Islamic religion" and a feeling of "humiliation" by other parties outside their identity group. Meanwhile, for Ahok's defenders, the binding value between them is a plurality, solidarity among ethnic immigrants (Chinese), and "Christianity." These socio-cultural similarities are then politicized and used as a tool to fight each other, which is then developed in the interest of electoral interests.

If analyzed using the concept of Politicized Collective Identity, the rivalry between the two camps that characterize the implementation of the 2017 DKI Jakarta Regional Election is initiated by the awareness of shared grievances. Both parties are aware that there are complaints about shared identity that is believed to bind each camp. For the Aksi Bela Islam side, the intended grievances are a sense of disappointment over their beliefs that have been (perceived) disgraced by local, regional leaders who by chance have different identities (Christian and ethnic Chinese immigrants) with themselves. Moreover, for this group, the Chinese identity attached to Ahok seemed to remind them of inequality, which led to an unharmonious relationship between Chinese and indigenous Indonesians during the Dutch East Indies colonialism. According to Freedman, as quoted by Sweinstani and Mariyah (2017), under the Dutch East Indies Colonial Administration, Chinese ethnic residing in Indonesia was placed in the second social strata (the foreign Orientals) to assume the status of a middle or as the class economic ruler of Dutch-East 
Indies. Unfortunately, (indigenous) Indonesian was placed in the lowest strata. This placement made the relationship among them was not harmonious.

Meanwhile, in the viewpoint of the Pro-Ahok camp, the intended grievances were a sense of disappointment because people who were regarded as leaders and relatives (especially for Chinese and Christian groups) had been accused of blasphemy. They believe that certain parties have manipulated these accusations for the black campaign efforts that hinder Ahok's way to lead DKI Jakarta again. A sense of disappointment also became even more intense when another party attacked Ahok's case in the realm of law.

As Simon and Klandermans have stated, awareness of shared grievances alone is not enough to be said to be a politically collective identity. The next stage is that both parties are looking for an external party to blame who is considered responsible for the grievances they feel. For the Aksi Bela Islam group, the person who was blamed was Ahok personally and for the Pro-Ahok camp the party that was blamed was Buni Yani as the person who distributed the pieces of the video of Ahok's official speech, and Rizieq who became the leader of the Islamic Defenders Front, which ran in a series of episode. Both parties also demand the state as the responsible party to accommodate their respective disappointments through the enforcement of the rule of law. The Aksi Bela Islam rallies consider that the state must imprison Ahok so that people who are considered blasphemous in their religion and belief are punished. The Pro-Ahok also requests that the state can prosecute Buni Yani and Rizieq as provocateurs of chaos in Jakarta.

The escalation of rivalry between the two sides has increased, when both are disappointed with the role of the state. In the perspective of the Aksi Bela Islam camp, disillusionment with the state can be seen from the perceived length of the legal process against Ahok. While in the perspective of the Pro-Ahok camp, disillusionment with the state was also based on the reason for the length of the legal process against Buni Yani and the unclear handling of the state in Rizieq. The disappointment of this group increased when the court finally ruled Ahok guilty and was sentenced to a heavier sentence than the claim filed.

The widespread disappointment of the two camps was shown by involving parties with the same identity attachment from outside DKI Jakarta. This momentum can even voluntarily invite reactions from sympathizers of each camp in various regions in Indonesia without having to be involved or invited by each camp in Jakarta. For example, there was also some action in Pontianak for the Aksi Bela Islam (Tempo, 2017), in Surabaya for the Thousand Action Candle (TribunNews, 20I7), and in other areas.

During this period of inflating identity sentiment, the two sides increasingly linked it to the ongoing DKI Jakarta political context. From the side of Aksi Bela Islam, incitement began by the order not to vote non-Muslim candidates because it discards the "value of Islam" in the propagandist point of view. This propaganda also has an impact on someone easily labeling other people as "kafir" ${ }^{12}$ when they have a different political orientation from what is "believed" by the propagandists. Meanwhile, anti-Chinese propaganda was again echoed due to this identity conflict. Several parties considered that if Ahok returned to led DKI Jakarta, this could be a sign of the rise of the Partai Komunis Indonesia (PKI or Indonesian Communist Party) which had long been considered as a banned organization in Indonesia. In addition, the propaganda for the existence of "Chinese-ization" in DKI Jakarta, which is the center of Betawi-lslamic culture also emerged. This propaganda was rolled out by looking at the example of Singapore, which is currently being dominated by Chinese ethnicity, whereas in past Singapore was part of the Malay-Islamic Sultanate (Burhani, 20I7). The propaganda of identity sentiment for electoral interests was also carried out by the Pro-Ahok camp. With the spirit of diversity and antiradicalism, they campaigned for Ahok as a prospective leader who represented the tolerance of diversity in Indonesia while others who cannot accept those kinds of differences were labeled as an I2 Kafir is an Arabic term of "unbeliever" or "disbeliever" 
intolerant person and violates the Bhineka Tunggal Ika (unity in diversity) value.

Mutual response to propaganda carried out by these two camps made the issue of identity as an effective weapon in the electoral campaign. Parties that utilize identity feuds as a means for electoral interests prove that there has been an expansion and shift in the issue of identity from a means of gaining recognition from other parties into a negative connotation phenomenon that full of short-term electoral interests. However, what happened in DKI Jakarta in 20I6-20I7 is known to have little difference in the pattern of politicization of collective identity with those constructed by Simon and Klandermans. In the context of the involvement of third parties, this party does not only participate in the vortex of identity conflict because it is involved/invited by the two conflicting camps. This third party is also involved voluntarily because of the urge to believe that what happened in DKI Jakarta is believed to be a common problem. This also confirms the opinion that Simon and Klandermans who said that the growing awareness of shared grievances and a clearer idea of who or what is responsible for those grievances reflect a distinct cognitive elaboration of one's worldview providing group members with a meaningful perspective on the social world and their place in it.

The demand to get the votes of more than half of Jakarta's voters made the implementation of the Jakarta elections be a regional election that badly needed large resources from candidates to be the winner of the election. Even though the average Human Development Index in DKI Jakarta is high, with a score of 79.60 , this does not necessarily guarantee DKI Jakarta voters to be rational voters who base their choices on programs carried by candidates. For some voter segments, the socio-cultural elements related to the closeness of candidates' identity to their identity is still become particular consideration in choosing the candidates. Such conditions are used by some parties to get as many voters as possible by conducting identity issues in a political campaign.

\section{Identity Politicization and Soft Security Threats}

Global dynamics forces countries to face soft security or non-traditional threats that threaten human security. In this section, it will describe how identity politicization in Pilkada DKI Jakarta disrupts societal security-as part of the security concept-mentioned by Barry Buzan (I998). The concept of 'societal security' has been described as sources of instability. The concept of leading is basically for soft security threats with a soft approach when the subject is not the state but the society. Societal security is dealing mainly with the preservation and affirmation of the society's identity and cohesion of society's members (Chifu, n.d.; Hough, 2004). The main forms of identity subject to life-threatening social discrimination are nationality, religion, sex, sexual orientation, disability, and ideology (Hough, 2004). In the case of the Pilkada DKI Jakarta, religious and ethnic identities are the capital of discriminators to determine their subject. When two or more groups each assume that the other is a threat to their life and identity, it can cause conflict (Wæver et al., I993). In fact, Buzan emphasized that countries as the main actors of security are strongly influenced by the security of individuals, groups, communities and other countries as a whole (W. T. R. Fox \& Buzan, I985).

Buzan said that most threats to societal security came from within the country. Indonesia was formed from an imagined community - as constructed by Benedict Anderson - consisting of identities that became Negara Kesatuan Republik Indonesia. This plurality is two sides of a coin: on the one hand it is a blessing, but on the other hand, it can be a source of conflict. Moreover, when this plurality has entered the political realm, politicized for electoral contestation in such a way as to achieve political goals. Indeed, this is a source of threat to Indonesian identity that has been, is, and will be built together. In the following sub-chapters, there are three important highlights due to the identity politicization that threatens societal security, namely (I) the emergence of negative sentiments towards minorities, (2) increasing cases of persecution and discrimination, and 
(3) polarization of society on social media. These three things constitute a threat and risk of horizontal competition - one of the threats to social security mentioned by Buzan - on a broader scale that also threatens national integration.

If analyzed, what happened during the Pilkada DKI Jakarta reflects what Fatic (2002) described the characteristics of soft security threats. First, the case of identity politicization is an internal threat to the state - it has nothing to do with inter-state relations - which can cause society polarization and fragmentation and increase negative sentiments towards minorities. Second, a soft approach is needed to prevent further conflict in order to overcome the problem of identity politicization such as political education which is the moral responsibility of the government and political parties. Third, in responding to threats, a policy-based approach is needed, such as the example of the Komisi Pemilihan Umum (KPU or General Elections Commission ${ }^{13}$ ) Regulation No. 4 of 2017 which prohibits the use of SARA (shortened from Suku, Agama, Ras, dan Antargolongan or ethnicity, religion, race, and intergroup relations) sentiments in political campaigns. Finally, the concept of security is broad, which includes human security and social security. Furthermore, it will be explained about three important highlights due to the politicization of identity.

\section{Negative Sentiments to Minorities}

In the context of the Pilkada DKI Jakarta, anti-Chinese sentiments have a long history and are still around economic disparities. Hatred towards Chinese Indonesians was the result of the disparate politics launched by Soeharto during his three decades of leadership. Soeharto forced the Chinese-Indonesians to assimilate while identifying them as non-indigenous (Freedman, 2003). Soeharto also marginalized Chinese Indonesians socially and politicly, banned their cultural and religious expressions, thus causing them to be forced to remove their Chinese names. This situation causes them to focus on business and become financially successful. I3 State's agency has responsibility and duty to organize elections in Indonesia
The ethnic wealth gap has long fed resentment among poorer "indigenous," Indonesia's mostly ethnic-Malay indigenous people (Allard \& Costa, 20I7). Following the fall of Suharto in I998, ethnic-Chinese and Chinese-owned businesses were targeted, where about I,ooo people were killed in the violence. Since the incident, there have been no other bloody events, but the tension against Chinese-Indonesians still exists. In fact, President Joko Widodo was the target of a black campaign which stated that he was Chinese and Christian.

For 20 years, Indonesia has undergone reform, negative sentiment towards Chinese Indonesians still exists in Indonesian society. Based on the research by Yusof Ishak Institute ISEAS, respondents from Indonesian society stated that Indonesian Chinese are more likely to be wealthy than "indigenous" (59.8 percent); Chinese Indonesian are usually at least middleclass (6o.I percent); and Indonesian Chinese have a natural talent for success in making money (68.I percent). Then, respondents' perceptions of Indonesian Chinese influence in the economy (62 percent) and politics (4I.9 percent) were also high. In other words, Chinese Indonesians are still considered to be playing a bigger role in the economy than in politics, despite their less visible role in the economy and more visible participation in electoral politics following post-I998 Indonesia's political liberalization. Speaking of the exclusivity of Chinese Indonesia, respondents argued that only Indonesian Chinese care about their own kind (48.4 percent); Chinese Indonesian may still harbor loyalty towards China (47.6 percent) ; Chinese Indonesians are too greedy and ambitious $(46.3$ percent); and it is hard to be a close friend with a Chinese Indonesian (44.I percent). This data reveals that almost half of the respondents stated that Chinese Indonesian still considered exclusive. Finally, respondents are asked if they are comfortable with a Chinese Indonesian in a position of political leadership. A majority of the respondents (64.4 percent) are uncomfortable with the notion, with no significant differences where gender and urban-rural locations are concerned. Furthermore, concerning Aksi Bela Islam rally, punishing blasphemy against Islam 
is most highly supported by respondents, and 58 percent of them consider it is important to vote a Muslim to a leadership position, coinciding with the level of support that Anies Baswedan received at the poll. This issue has currency beyond Jakarta and the gubernatorial election (Fossati, Yew-Foong, \& Negara, 20I7).

Negative sentiment was then escalated with anti-Chinese rhetoric from leaders in the community. Bachtiar Nasir's statement - the leader of the mass organization of the National Movement of Fatwa ${ }^{\mathrm{I} 4}$ Guards Majelis Ulama Indonesia ${ }^{15}$ ( GNPF-MUI) -To Reuters is that Indonesia's Chinese wealth is an inequality that is at the root of serious social problems in Indonesia (Allard \& Costa, 20I7). According to him, Chinese Indonesian does not show a sense of justice and generosity. Vice President Jusuf Kalla told Tirto also confirmed this, according to him, economic disparity in Indonesia is dangerous because most of the rich are Chinese or Christian Chinese, while most of the poor are Muslims and/or Christian (Haryanto, 20I7). This anti-Chinese rhetoric continues to be echoed during the escalation of the Aksi Bela Islam rally until now. This rhetoric has the potential to mislead the public if it is not explored further scientifically because single ethnic and religious factors cannot fully explain social inequality in society. The deception of this public figure statement also has the potential to form wrong perceptions or sentiments towards minority groups so that it also has the potential to be manifested in a discriminatory form. This certainly threatens the minority's human security because it does not work in accordance with the corridors of democracy that uphold human rights and minority protection. The increasing negative sentiment towards the majority group also has the potential to become the root of problems in

I4 Fatwa is a nonbinding legal opinion on a point of Islamic law (sharia) given by a qualified jurist in response to a question posed by a private individual, judge, or government.

I5 Majelis Ulama Indonesia or Indonesian Ulema Council is Indonesia's top Muslim clerical body. The council comprises Indonesian Muslim groups including Nahdlatul Ulama (NU), Muhammadiyah, and smaller groups such as Syarikat Islam, Perti, Al Washliyah, Math'laul Anwar, GUPPI, PTDI, DMI, and Al Ittihadiyyah. horizontal competition and conflicts that will shape the fragmentation of society.

\section{Persecution and Discrimination}

It turned out that the negative sentiment towards the minority did not stop at the level of thinking, but it had already manifested in persecution and discrimination. ISEAS research confirmed by the rampant persecution cases throughout and after the Pilkada DKI Jakarta period which targeted minorities. There is not only an increase in negative sentiments towards Chinese Indonesian ethnicity but also differences in political choices are also the reason for persecution. Persecution is a systematic action of individuals or groups to other individuals or groups because of religious, ethnic, cultural and political issues, which cause suffering, abuse, imprisonment, isolation, fear, and pain (Rempell, 2013).

Kontras (Komisi Untuk Orang Hilang dan Korban Tindak Kekerasan or The Commission for Missing Person and Victims of Violence) noted that there had been 60 acts of persecution in various regions from October 2016 to June 20I7; namely when the video of Basuki Tjahaja Purnama's speech in the Kepulauan Seribu was uploaded and became a source of escalation of public anger, until after Ahok was sentenced to prison. The prominent persecution case at that time was intimidation and threats received by Doctor Fiera Lovita in Solok and teenagers who were considered to have mock ulama and mass organizations in their social media uploads. This post triggered the netizen conversation and followed by verbal and non-verbal intimidation by the Islamic Defenders Front (FPI) and coercing so that they must remove the post, apologize, and promise do not repeat it in the future (Aziz, 20I7).

According to the results of the Kontras monitoring, the highest number of persecution actions were in October 2016, namely as many as II cases related to the prohibition of certain group/minority worship, the prohibition of places of worship, and the destruction of places of worship dominated by intolerant mass organizations. In the aftermath of the first round of the elections, there was also an increase in 
March 20I7, where there were Io cases related to sweeping, arrest, intimidation, and dissolution of groups/individuals deemed as heretical. The basic motive for the act of persecution is religion and politics. Trends in acts of persecution are prohibition (24 cases), intimidation (2I cases), forced dissolution (I9 cases), rejection (I7 cases), arbitrary arrests (II cases), sealing (5 cases), persecution ( 4 cases), and damage ( 3 cases). The most action is prohibition and intimidation related to certain minority activities that are deemed not in accordance with religious beliefs and lack of religious tolerance, which results in forced dissolution without the presence of officials and government (Kontras, 20I7).

Conceptually, the democratic framework is a majority rule that protects minority rights. Then, philosophically, the values of Pancasila and the motto of Bhinneka Tunggal Ika (unity in diversity) express that, in fact, the Indonesian nation is plural but remains united under Negara Kesatuan Republik Indonesia (Republic of Indonesia). Therefore, all Indonesians from various ethnic and religious backgrounds are separate entities that form the identity of plural Indonesia. Furthermore, Indonesia has ratified the International Covenant on Civil and Political Rights (ICCPR) in Law No. I2 2005 about International Covenant on Civil and Political Rights, specifically Article 27 which states the protection of minorities so that this agenda should be a government priority.

\section{Social Media Polarization}

In an era of rapid technological and information development, social media plays an important role in daily activities. Data from The New Trend among Indonesia's Citizens, internet penetration has reached $44 \%$ of Indonesian people, the 3 rd highest after television and static outdoors. This figure increased significantly compared to 5 years ago, which was only $26 \%$ of the Indonesian population (Nielsen, 20I7). This shows that what happens on the internet and social media can be broad and rapid public consumption. Aksi Bela Islam rally was also driven by information dissemination and mass mobilization through social media. A video clip of Basuki Tjahaja Purnama's speech in the Kepulauan Seribu uploaded by Buni Yani to YouTube - a social media site for sharing videos - quickly spread through social media as well. The call for the Aksi Bela Islam was also mobilized on the Facebook, Twitter, Instagram, and even WhatsApp and Telegram chat applications. Such a mechanism shows that social media plays a role in shaping opinion and mobilizing the masses.

Based on Social Network Analysis (SNA): Retweet Network conducted by the Drone Emprit on October 17-3I, 20I6, and on 3-4 November 20I6, there was a polarization of interaction on Twitter. The Islamic Defense Pro-Action Cluster is dominated by user-interaction and other interactions like @DPP_FPI, @posmetroinfo,@wartapolitik, @amaBlenk, @panjimascom, @MohArifWidarto, and @syihabrizieq. While in the counter-Islamic Action counter, dominated by @ulinyusron, then @sahaL_AS, @Nadir_Monash, @GunRomli @kurawa, @ PartaiSocmed, @muchlis_ar, and @SlametMuslim. The topics discussed are in the form of hashtags \#PenjarakanAhok is the one who gets the most retweets (66o retweets), then there is also the hashtag \#UmatlslamDukungMUI, \#AksiBelalslam, \#AksiBelalslam2, \#JagaNKRI, \#AksiBelalslam4Nov2oi6, \#KamiAhok, and \#PenjarakanAhokPenistaAgama. Polarization interactions in the 4II rally was not acute because the @detikcom account tries to mediate the situation with the \#JakartakuDamai hashtag. ${ }^{16}$

I6 In accordance with Ismail Fahmi's presentation (Founder of PT Media Kernels Indonesia) at Public Lecture at FTI Indonesian Islamic University, Yogyakarta on November I9, 2016. 


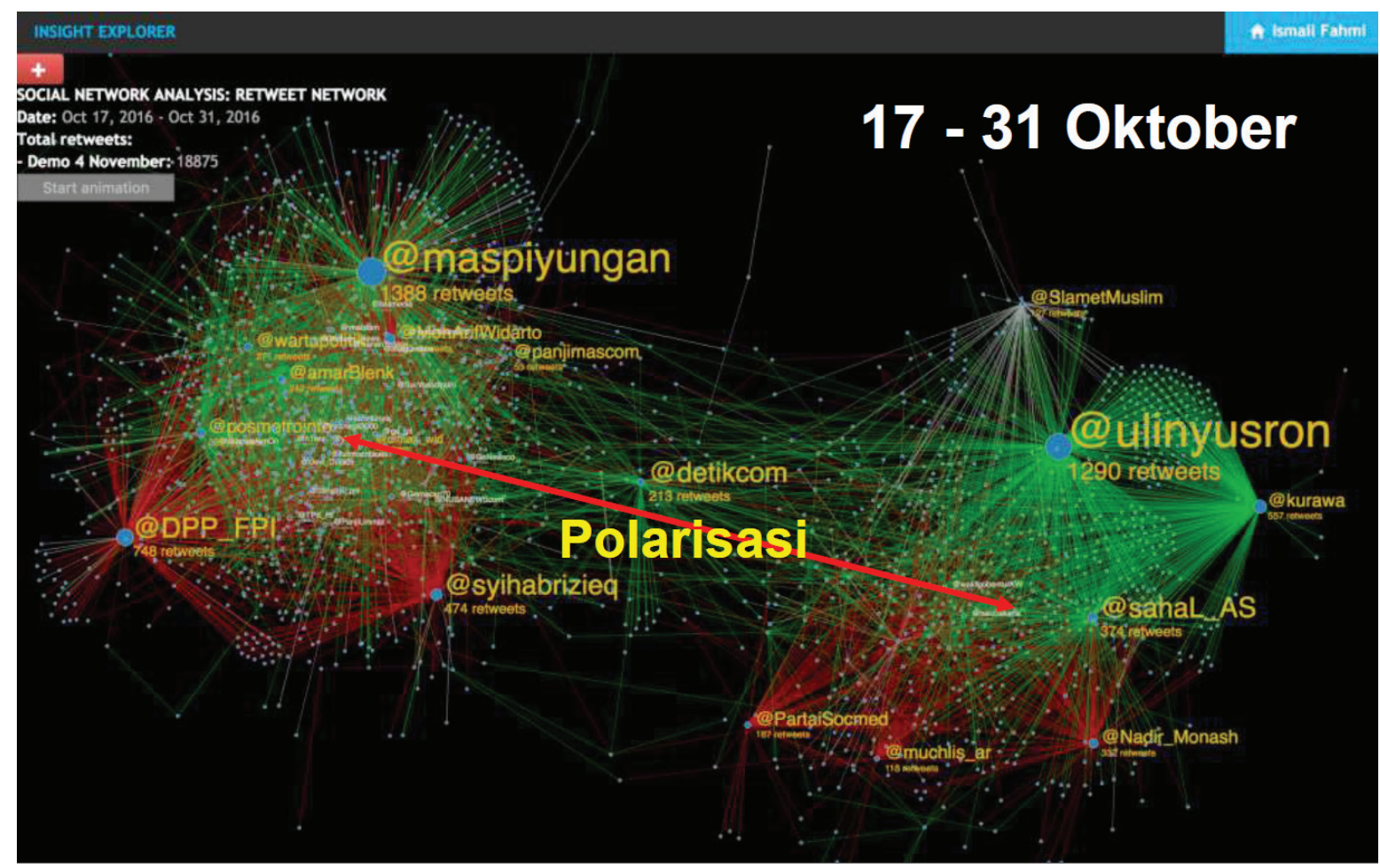

Picture I Drone Emprit's Social Network Analysis (October I7-3I, 20I6)

Source: Ismail Fahmi's presentation on 2016

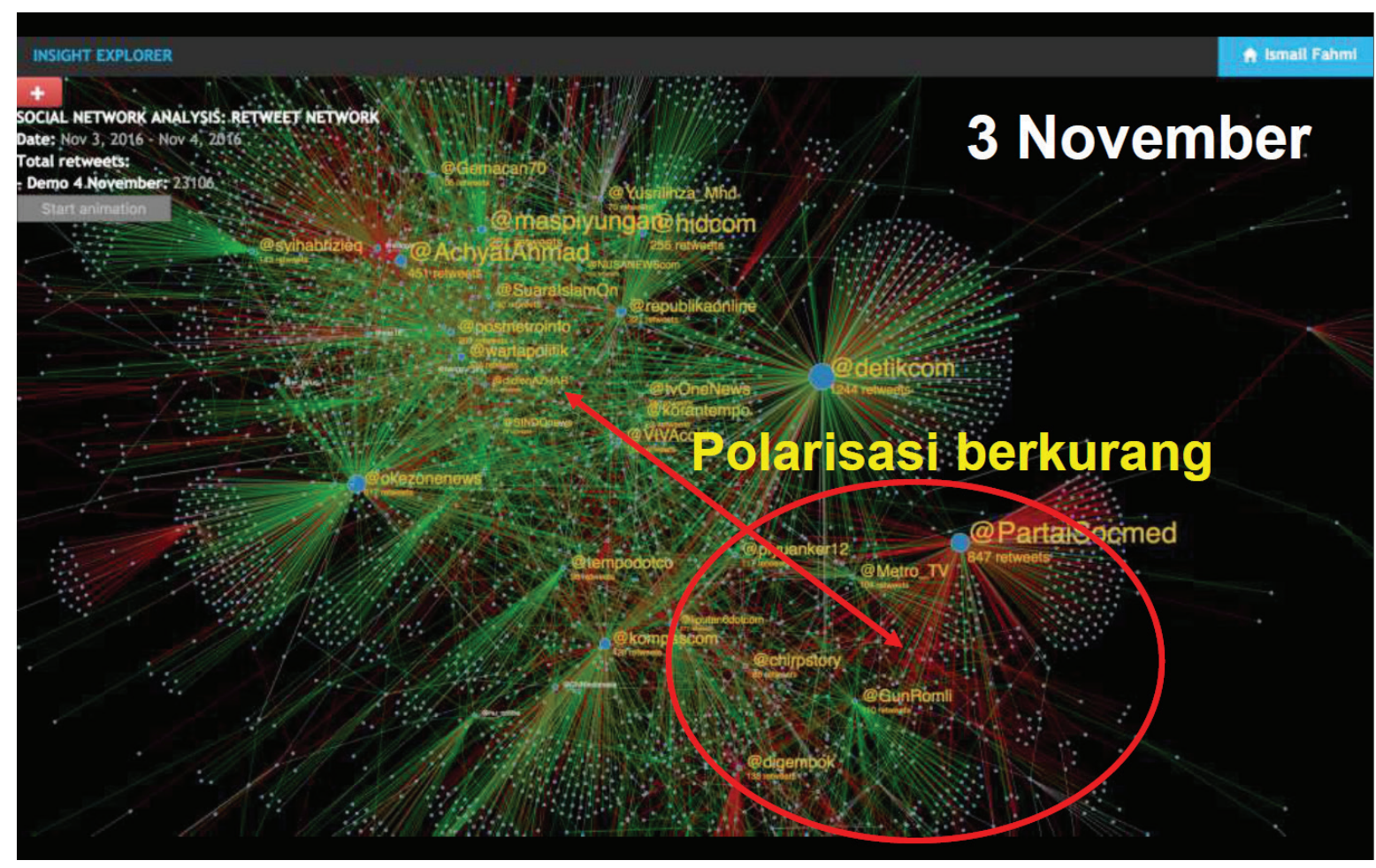

Picture 2 Drone Emprit's Social Network Analysis (November 3-4, 2016)

Source: Ismail Fahmi's presentation on 2016 
Political buzzer factors also influence this polarization. Based on research by the Center for Innovation Policy and Governance (2017), a buzzer is an individual or an account that has the ability amplification message in the way of attracting the attention to establish a conversation and move with a particular motive. Buzzers usually have an extensive network in which they have many followers of social media accounts. This enables them to create content in context, persuasive, and driven by certain motives (money and voluntary). Political parties or figures need buzzers to promote themselves and programs so that people know them better and boost popularity. Some buzzers work in teams, such as the Muslim Cyber Army, or work individually. Because buzzer has an extensive network and is able to spark persuasive talks, buzzer plays an important role in shaping public opinion and conversations on social media (Center for Innovation Policy and Governance, 2017).

Besides the buzzer factor, echo chamber factor is also crucial in polarization in social media. People who live in an echo chamber will only hear the opinions they want to hear. This phenomenon can explain why fake news, hoaxes, and conspiracy theories tend to only develop in certain circles. In relation to social media, people will judge each post based on its benefits for themselves so that they tend to read people who are social, political, and cultural in their terms. The danger of a phenomenon like this is that someone will confirm confirmation, where they will tend not to hear the other side of a story. This confirmation bias also explains why the political reasoning of the people can be directed easily, let alone escalated with SARA (Indonesian abbreviation for ethnicity, religion, and racial divisions) sentiments.

\section{CONCLUSION}

The experience of DKI Jakarta Local election in 2017 has shown us that identity was not only used only as a tool to get recognition from others but also has shifted to the negative connotation. The identity that is inherent to each individual then constructed to be politicized collective identity that used to the short-term electoral interest.
As the kind of politicized collective identity, the awareness of shared grievances of each group that sparked the manipulation of identity issue was inflated broadly as well as involved third partied to join the conflicting situation where they were in. The involvement of others even happened not only by invitation by the main group but also by the volunteering action due to the same shared identity among them.

It can be concluded that identity politicization that occurred during the Pilkada Jakarta is a soft security threat to human and societal security. This is because the politicization of identity has caused three significant effects, namely increasing negative sentiments towards minority groups, especially Chinese and Christian Indonesian; increasing the number of acts of persecution and discrimination carried out because of differences in religion, ethnicity, or political choice; and causing public polarization on social media until now. Negative sentiment towards minority groups is a threat to our plural Indonesian identity. A long history shows that Chinese Indonesian has become part of Indonesian society but marginalized during the New Order era. This increasing negative sentiment has the potential to lead to acts of racial persecution and discrimination. Since the DKI Jakarta Pilkada, the number of persecution cases has increased, the highest number of prohibition and intimidation cases have been carried out by vigilant mass organizations. Then, on social media, there was also the polarization of the opinion of the people who were pro and contra of the Aksi Bela Islam rally, which was exacerbated by the confirmation bias carried out by both parties.

This research is expected to be a common idea that unhealthy competition in local elections using identity sentiment threatens the integrity of Indonesian, specifically our identity as a nation. To the stakeholders, it is expected that this research can provide a research-based recommendation. To the actors of politics, this research is hoped to inspire them to continue running for elections in a healthy way using programs and innovations. 
The recommendation proposed is the establishment and strengthening of national identity to all components of the Indonesian nation, including actively involving high-profile figures, i.e., community leaders, religious leaders, and cultural leaders. In understanding the national identity, it should be emphasized that the Indonesian people are diverse, so that diversity should not be politicized to gain power.

\section{REFERENCES}

A'raf, A. (2015). Dinamika Keamanan Nasional. Jurnal Keamanan Nasional, I(I), 27-40.

Afala, L. M. (2018). Politik Identitas di Indonesia. Malang: UB Press.

Allard, T., \& Costa, A. B. Da. (20I7). Exclusive - Indonesian Islamist leader says ethnic Chinese wealth is next target. Retrieved October 9, 20I8, from https://www.reuters. com/article/uk-indonesia-politics-clericexclusive/exclusive-indonesian-islamistleader-says-ethnic-chinese-wealth-is-nexttarget-idUSKBNi88I7N

Aziz, A. (2017). Kasus-Kasus Persekusi Bunyikan Alarm Kebebasan Berekspresi. Retrieved October 4, 2018, from https://tirto.id/ kasus-kasus-persekusi-bunyikan-alarmkebebasan-berekspresi-cpT2

Buehler, M. (2009). Islam and democracy in Indonesia. Insight Turkey, II(4), 5I-63. https:// doi.org/Io.Io80/I4683840500II9494

Burhani, A. N. (20I7). Ethnic Minority Politics in Jakarta's Gubernatorial Election. ISEAS Yusof Ishak Institute.

Buzan, B., Wæver, O., \& Wilde, J. De. (I998). Security: A new framework for analysis. National Bureau of Economic Research Working Paper Series. https://doi.org/I0.2307/2586187

Caballero-Anthony, M., \& Emmers, R. (2016). Understanding the Dynamics of Securitizing Non-Traditional Security. In M. CaballeroAnthony, R. Emmers, \& A. Acharya (Eds.), Non-Traditional Security in Asia: Dilemmas in Securitization (pp. I-I2). New York: Routledge.

Center for Innovation Policy and Governance. (20I7). Di Balik Fenomena Buzzer: Memahami Lanskap Industri dan Pengaruh Buzzer di Indonesia. Jakarta. Retrieved from cipg.or.id/buzzer

Chifu, I. (n.d.). Societal Security: An Agenda for the Eastern Europe. Bucharest. Retrieved from http://www.cpc-ew.ro/pdfs/societal_security. pdf
Dumm, T. L., \& Young, I. M. (I992). Justice and the Politics of Difference. The American Political Science Review. https://doi. org/I0.2307/1964259

Fatic, A. (2002). Conventional and unconventional - "hard" and "soft" security: the distinction. SEER: Journal for Labour and Social Affairs in Eastern Europe, 5(3), 93-98. Retrieved from http://www.jstor.org/stable/43292068

Fossati, D., Yew-Foong, H., \& Negara, S. D. (20I7). The Indonesia National Survey Project: Economy, Society, and Politics. Trends in Southeast Asia, (IO).

Fox, C. (20I8). Candidate-centric systems and the politicization of ethnicity: evidence from Indonesia. Democratization, 25(7), II9O-I209. https://doi.org/Io.Io8o/I35I0347.20I8.I46I 207

Fox, W. T. R., \& Buzan, B. (I985). People, States, and Fear: The National Security Problem in International Relations. International Journal. https://doi.org/10.2307/40202323

Freedman, A. (2003). Political Institutions and Ethnic Chinese Identity in Indonesia. Asian Ethnicity. https://doi. org/I0.1080/1343900032000II7259

Ganjar Herdiansah, A., \& Heni Ismiati, dan. (20I7). Pembelahan Ideologi, Kontestasi Pemilu, Dan Persepsi Ancaman Keamanan Nasional: Spektrum Politik Indonesia Pasca 2014? Jurnal Wacana Politik-ISSN, 2(I), 6I-73.

Germany Federal Government. (2016). White Paper on German Security Policy and the Future of Bundeswehr. Berlin. Retrieved from https://www.bundeswehr.de/resource/ resource/.../2016 White Paper.pdf

Haryanto, A. (2017). Wapres: Kesenjangan Kemiskinan di Indonesia Cukup Berbahaya. Retrieved October I0, 20I8, from https:// tirto.id/wapres-kesenjangan-kemiskinan-diindonesia-cukup-berbahaya-cjKC

Herdiansyah, A. G. (20I7). Politisasi Identitas dalam Kompetisi Pemilu di Indonesia Pasca 2014. Jurnal Bawaslu, 3(2), I69-I83.

Horowitz, D. L. (I998). Demokrasi Pada Masyarakat Majemuk. In L. Diamond \& M. F. Plattner (Eds.), Nasionalisme, Fonflik Etnik, dan Demokrasi. Bandung: ITB Press.

Hough, P. (2004). Understanding Global Security. London: Routledge.

Kementerian Pertahanan. (2015). Buku Putih Pertahanan Indonesia. Jakarta: Kementerian Pertahanan RI. Retrieved from https://www. 
kemhan.go.id/wp-content/uploads/20I6/04/ BPPI-INDO-20I5.pdf

Klandermans, P. G. (20I4). Identity Politics and Politicized Identities: Identity Processes and the Dynamics of Protest. Political Psychology, 35(I), I-22. https://doi.org/Io.IIII/pops.I2I67

Kontras. (20I7). Pilkada, Persekusi, dan Teror Negara. Jakarta. Retrieved from https://www.kontras. org/data/20I706I5_Pilkada_Persekusi_dan_ Teror_Negara_09i13j549ur35.pdf

Mietzner, M. (2014). Indonesia's 20I4 Elections. How Jokowi Won and Democracy Survived. Journal of Democracy, 25(4), III-I25.

Nielsen. (20I7). The New Trend Among Indonesia' Citizens: How and where digital consumers are watching content online. Jakarta.

Ozolina, Z. (2016). Societal Security: Conceptual Framework. In Z. Ozolina (Ed.), Societal Security: Inclusion-Exclusion Dilemma, a Portrait of the Russian-speaking Community in Latvia (pp. I3-28). Riga: Zinatne. Retrieved from http:// www.mime-project.org/outcomes/Publications/Societal Security iekslapas_201604I8. pdf

Paskarina, C. (20I7). Narasi Identitas Populis dalam Demokrasi Electoral. Jurnal Bawaslu, 3(2), 285-296.

Rempell, S. (2013). Defining Persecution. Utah Law Review, 20I2(I). Retrieved from https:// papers.ssrn.com/sol3/papers.cfm?abstract_ id=I941006

Simon, B., \& Klandermans, B. (200I). Politicized collective identity: A social psychological analysis. American Psychologist, 56(4), 319-331. https://doi.org/I0.I037/0003-066X.56.4.319
Sweinstani, M. K. D., \& Hasanah, R. U. (20I7). Integrasi Nasional dan Eksklusionaris Identitas Dalam Pilkada 2017: Studi Kasus Pilkada Maluku Utara, DKI Jakarta, dan Kalimantan Barat. Jurnal Bawaslu, 3(2), 185-I98.

Tajfel, H., \& Turner, J. (I979). An integrative theory of intergroup conflict. In The Social Psychology of Intergroup Relations (pp. 33-47). https://doi. org/Io.IoI6/Soo65-260I(05)37005-5

Theiler, T. (2003). Societal security and social psychology. Review of International Studies. https://doi.org/Io.I017/S0260210503002493

Ufen, A. (2008). Political party and party system institutionalization in Southeast Asia: lessons for democratic consolidation in Indonesia, the Philippines and Thailand. The Pasific Review, 2 (3 July 2008), 327-350. https://doi. org/DOI: 10.1080/09512740802134174

United Nations Development Programme. (1994). Human Development Report 1994. Human Development Report. https://doi.org/http:// hdr.undp.org/sites/default/files/reports/255/ hdr_I994_en_complete_nostats.pdf

Wæver, O., Buzan, B., Kelstrup, M., \& Lemaitre, P. (I993). Identity, Migration and the New Security Agenda in Europele. London: Pinter.

Weinstock, D. M. (2006). The real world of (global) democracy. Journal of Social Philosophy, 37(I), 6-20. https://doi.org/Io.IIII/j.I4679833.2006.00300.x

Yuval-Davis, N. (1997). Gender and Nation. New Delhi, India: SAGE Publication India. 